\title{
Identity Reconfiguration of Immigrants in Portugal
}

\author{
Ricardo Vieira* and Maura Mendes \\ CIID, Research Center for Identity and Diversity, Leiria Polytechnic Institute, Rua das Olhalvas 2414- \\ 016 Leiria, Portugal
}

* Author to whom correspondence should be addressed; E-Mail: rvieira@esecs.ipleiria.pt; Tel.: +351-244845051; Fax: +351-244845059.

Received: 31 May 2010 / Accepted: 23 June 2010 / Published: 1 July 2010

\begin{abstract}
The starting point is the principle that there is no immigrant culture, but rather, different ways of living, coexisting and identifying oneself within the cultural worlds that each subject crosses on his or her social path. Here we study Brazilian immigrants in Portugal, working with the first wave (starting at the end of the 1980s) and the second wave (at the turn of the 20th to 21 st century). We intend, firstly, to show how identity is reconstructed between two banks: the departure culture and the arrival culture. Secondly, we intend to give a voice to the most silent in the understanding of immigrants: the process of identity reconstruction of Brazilian immigrants is presented, resulting from ethno-biographic interviews. We will consider the cultural transfusion theory and observe the heterogeneous ways of living between cultures, whether by rejecting the departure culture (the Oblato's case), refusing the arrival one at a given moment (the mono-cultural subject according to the source culture), living in an ambivalent manner between the two (the multicultural self), or, finally, inventing a third bank, as the poets say, which corresponds to an attitude of including the cultural differences through which one crosses during his or her life history in an intercultural self (the Intercultural Transfuga).
\end{abstract}

Keywords: personal identities; first bank; second bank; metamorphosis of identity; ethno-biographical interview; multi-cultures; intercultural self; bicultural self 


\section{Introduction}

When we talk about immigrants, there is probably a greater tendency to think about what unites them culturally rather than what distinguishes them. In this text, on the contrary, the starting point is the principle that there is no immigrant culture, but rather different ways of living, coexisting and identifying oneself with the cultural worlds that each subject crosses on his/her social path. The basis of democratic life cannot be "Us" the Nation, but the multiple "I"s that constitute a country's or the Republic's citizenship, even when people join together to defend their interests and to overcome inequality of opportunities resulting from different social classes, genders, status backgrounds, etc.

\section{The Culture of the Immigrants}

For centuries, Portugal was considered a country of emigration, which became accustomed to seeing its people leave for the widest variety of corners of the world. Nevertheless, in recent decades, it has been transformed into a country of immigration, a phenomenon associated with decolonization and its entry into the European Union. Portugal occupies its own place within the framework of recent developments in European societies. Lages et al. [1] reported that Portugal has passed through a substantial transformation: "From an emigrant country that saw many of its children embark for the Americas, or, in the 1960s, "jump" across the border towards Europe, above all over the last 15 years it has become a country of much immigration".

Cruz [2] points out that in less than half a century, "in an almost imperceptible, episodic phenomenon, immigration has become a notable and striking flow in our collective experience, giving Portuguese society a multicultural nature that we didn't know in the past". Today, Portugal has nearly half a million legal immigrants, who represent around five per cent of the total population, in addition to the number of undocumented immigrants, which has already surpassed one hundred and fifty thousand people [3].

With the entry of thousands of foreigners into Portugal, an accentuated economic immigration with the entry of Eastern European populations, quoting Souta [4], "reinforces the multicultural matrix marked since centuries ago by traditional minorities such as the gypsy community, the Jewish and the deaf population (who express themselves in their own language, the Portuguese sign language)".

In this article, we will explore the identities' metamorphosis of Brazilians in Portugal. The occupational structure of the Brazilian immigrant population in Portugal may be divided into three broad categories: highly qualified professionals, where the presence of a significant number of professionals stands out; specialized workers and small business owners; and unqualified workers, where refugees and undocumented immigrants predominate. We will enable some of the voices of these immigrant cases to be heard.

In fact, the social interaction started as a renewal of attitudes and forms of cultural expression in Portugal. The multi-culturality of Portuguese society is definitely an irreversible reality, mainly in most industrialized urban areas, where there are more work opportunities. As it occurs in all social interaction, researching findings by Vieira, Trindade and Mendes [5-7] show that Brazilian immigrants have changed their original identities, metamorphosing themselves. 
We shall reflect on the transformation and the metamorphoses of identity that occurred to these immigrants from Brazil. We will discuss how their social paths and life experiences make them an "other", very different from their peers who stayed in their original country, "which constitutes one of the greatest problems for people who have immigrated to return to their countries: they aren't recognized, so changed are they, and many times more culturally than materially" accordingly to Cuche [8]. It is convenient to register, breaking with some common views, that the person who has immigrated is not a representative of their country's culture or of their original community.

Cuche [8] points out that "The so-called 'culture of the immigrants is, therefore, in reality, a culture defined by others, in function of the interests of others, from ethnocentric criteria. The 'culture of the immigrants' is all that that makes them appear different, and only that. [...] The more an individual is perceived as different, the more they are considered 'immigrant'. Of the cultural systems of the immigrants themselves, they retain only what comforts the dominant representation of these cultures, namely the aspects most visible and most surprising. The most 'exotic' 'traditions', 'customs', 'cultural traits' $[\ldots]$ that allow the definition of the immigrated person as immigrant, that remind them of their origins and, according to Sayad's expression, 'call them to their origins', which is a way of 'putting them in their place'."

For this reason, we refer to immigrated persons, in the plural, and to their multi-cultures, to mark the heterogeneity within their universe, and assuming more the idiosyncrasies of each one's identity than, actually, the cultural identity of the citizens from Brazil presented herein.

Accordingly to the same author [8], "We cannot, therefore, outline a single framework for the cultures of those who have immigrated, as they only exist in the plural, in the diversity of situations and modes of interethnic relations. These cultures are complex and evolving systems, such that they are permanently reinterpreted by individuals whose categorical interests may be diverse, according to sex, generation, the place occupied in the social structure, etc."

\section{The Cases and the Methodology}

Considering the standpoint of Vieira and Trindade [5,6], this article is an essay to understand how each immigrant is not a structure, but rather a process in a continuous metamorphosis of his/her personal identity. With this in mind, we must underline that this is not an experimental study; this paper is an ethnographical and ethnobiographical approach to the transformation process of four Brazilian immigrants who live with their ontological doubts concerning a unique identification (to the first or to the second bank of the river, metaphorically speaking) or a multicultural identification. This approach is based on the cultural transfusion theory, as referred by several authors $[6,9,10]$, which invests in the individual dynamics and the way each person manages different identitary belongings, breaking from the American culturalism and the patterns of culture, presenting the subject as the statistical sample of the group that he or she lives with daily. In accordance with this, we will study the cultural transformation which happened to two men and two women originating from the designated first immigration wave: Márcio, 48 years old, university professor; Rowney, 55 years old, dentist; Antónia, 47 years old, self-employed beautician; and Nívea, 45 years old, radio journalist.

After contextualizing the ongoing study and considering several dialogs about integration difficulties in the welcoming country; as well as concerning failures and successes occurred in the 
arrival culture adaptation and after gaining empathy with the four immigrants in order to communicate in a personal ambiance, interviews were schedules in the form of conversation [11]. The interviewees were previously given the interview guide, which had three main topics: the departure from the origin country (what was my profession? Who was I before I immigrated?); arrival in the welcoming country: cultural shocks, duality of belonging feelings ("what is my profession now?"; "Who am I?"); and the future perspectives ("what is my aim? to return? to stay?"). Each interview lasted about three hours. The investigator tried to listen, rather than talk. Moreover, questions emerged from what was said and reflections by the interviewees rather than anchored in pre-established categories (ethnographic interview). On the other hand, the questionings promoted auto-reflection, focusing on life's ontological dimension rather than on the pragmatic one [9], taking biographical notes into account, the interviews were designated as ethnobiographical [5,12].

We assume the ethnographic and interpretative position defended by Geertz [13], organizing the text by titles and subtitles which do not match as aprioristic concepts in order to be filled with data. Subtitles inscribe themselves both in a hermeneutical perspective and sense findings from studied individuals, unlike a verificationist, nomothetic and positivist theory. As Bourdieu taught in his La Misère du Monde [14], the focus must be on understanding, instead of verifying. Although this dualistic Dilthey's perspective, we need to say, as Bourdieu did, that understanding (verstehen) and explaining (erklären) work simultaneously.

In this paper, obviously, we will only be able to offer some of those interviewing process excerpts, which allow to evidence identity management, being closer to the departure cultures or the arrival cultures.

\section{Culture(s) and Identity(ies) of Immigrants}

Let us reflect a little on how identity is reconstructed between two banks: the departure culture and the arrival culture. In doing so, we will consider the cultural transfusion theory $[5,10]$ and observe the heterogeneous ways of living between cultures, whether by rejecting the departure culture (the Oblato's case), refusing the arrival one at a given moment (the mono-cultural subject according to the source culture), living in an ambivalent manner between the two (the multicultural self), or, finally, inventing a third bank, as the poets say, which corresponds to an attitude of including the cultural differences through which a person crosses during his life history in an intercultural self (the Intercultural Transfuga).

"At the end of the day, any one of us could have been any other. Each one of us is a potentiality that could have been realized in another time, in another place, in another culture. Similarly, each other is a potentiality of me, which I myself did not realize: but it is me in a potential state, it is the aspect of my full manifestation. Thus, each one of us contains within ourselves all humanity. [...] Localized differences need to be understood as an expression of general similarity that allow humankind to be different; structures beyond group, ethnic or social "identities", which allow them in their relational aspects" [15].

Effectively, from the perspective of this article, all prediction is out of question. All mechanistic and sociological analysis of meeting of cultures is off limits. The socialization process and the learning experiences that occur during a life period change personal identity in an unpredictable manner. 
Hall [16] reports that "Some people argue that "hybridity" and syncretism- the fusion between different cultural traditions - are a powerful source of creativity, producing new forms of culture, more appropriate to late modernity than the old and contested identities of the past. Others, meanwhile, argue that hybridism, with indeterminacy, "double consciousness" and the relativism that it applies also has its costs and dangers".

We perceive identity as a complex construction, established through the relationship with the other, and not as an existential state. As Vieira [17] states, "if identity implies some constancy, it is not however an undefined repetition of the same, but rather dialectic, by integration of the other in the self, by the change of continuity".

Those who experience migratory contexts, throughout multiple cultural references and complex situations, tend towards identity hybridism or miscegenation. As Hall [18] emphasizes, "in situations of Diaspora, identities become multiple". In doing so, the search for identity feelings and belonging become complex, requiring the subjects to perform a major reflexivity and a continuous self (re)construction, appealing to their internal mechanisms, allowing them to generate their subjectivities and idiosyncrasies. Taking into account that migrants, as told by Sarup [19], "have one foot in each place", it's presumed that there's a radicalization of their hybrid and miscegenated identities, by the "process of pluralization of the structural spaces where identity is formed" underlined by Stoer and Magalhães [20].

The plural self invents itself as each moment passes, in a multiplicity of belongings and symbolic places, in a continuous process of miscegenation: each one is what he becomes through the relationships he establishes and through the original form in which he appropriates the other, making the other his own, in a constant balance, so that his life project makes sense.

Wieviorka [21] allows a holistic perspective on this matter: "Miscegenation authorizes, therefore, cultural change and transformation, but from the base, i.e. through individual processes, even if these repeat themselves enough to give the impression of a group process [...]. Miscegenation would be, in other words, a subjectivating factor, as far as it confers on subjects the faculty of constructing themselves and translating themselves into acts. The same is to say that miscegenation does not only imply the mixture of cultures. When there is a meeting of strong cultures that does not lead them to disappear, processes of reciprocal influence may take place, (of acculturation, as would be said in other words), of innovative, and not necessarily impoverishing, transformations [...], may invent for themselves original cultural forms that do not supplant entirely those from which they extract their origin".

Identity takes on a changeable, multidimensional process, resulting from a social construction and, thus, resulting also from its complexity. From this perception, the subjects seek identity coherence by increasing the ontological security, allowing them the "continuity of their personal self-identity", as told by Giddens [22]. Therefore, as said by Camilleri [9], identity "is not a mechanical constancy, or an indefinite repetition of the same, but dialectic through the integration of the other in the same, of the change in the continuity". 


\section{Between Here and There: Identities in the Gerund}

\section{MÁRCIO}

\section{The Departure}

Márcio has been in Portugal for 18 years. He came from Rio de Janeiro. After his degree in Economics, he emigrated from Brazil to Portugal, a country that was his second choice, to do his Masters degree in European Economics at the University of Coimbra. He is married to a Brazilian whose parents are Portuguese and he has a little daughter.

"I came to Portugal because I belong to an immigration wave obsessed with the United States, the fascination that the USA perniciously hold over the whole of Latin America and over Brazil. I wanted to study Economics in the USA, at the time I had my savings, a car and I made some calculations about my life, and I saw that I didn't have the means, I couldn't get a scholarship to go to the USA. [...] I quit my job, I grabbed my savings, sold my car, my romance also finished and I was free for the world. I grabbed my bags and left. The other memory that will stay in my head, in emotional terms, is that I'd never been outside Brazil, it was the first time, I was 23 years old at the time. [...] my mission was to leave Rio [de Janeiro] and get to Coimbra, I began to do some research on Coimbra."

\section{The Escape to the Third Bank}

Unlike hybridity, miscegenation is not fusion. It is disjunction. It is an escape to a third bank of the river. This escape becomes conscious when the looks and the speeches that others give us back, either from the first or the second bank, tell us that we don't belong neither to one nor the other. The double belonging that generates ambiguity is, thus, objectified and the departure to a third bank of the river, as Guimarães Rosa asserts, may happen.

“No, I don't consider myself Brazilian-Portuguese. I'm a Brazilian, all my documentation is Brazilian, but, deep inside, I am Luso-Brazilian. Today, anywhere I might be in this world, if somebody derides Portugal, I feel that taint. When I analyze things, I usually make a mental and emotional comparison, which is the following: when someone speaks badly about us or our country, even though how critical we can be about our country, we tend to step back, because there is a mark that is left, and today I feel as uncomfortable if they speak badly about Brazil as I feel about Portugal, i.e., when I go to Brazil and some Brazilian makes a negative criticism about Portugal, this affects me. By the same token, if someone in Portugal makes a negative criticism about Brazil, it also affects me. [...] Nobody knows where the other comes from. And today I am ethnically ambiguous because I arrive in Brazil and I'm not Brazilian, for people who don't know me. If I arrive today in Brazil and start to speak, I'm not a Brazilian; and here in Portugal, if I speak, I'm not a Portuguese. It comes from the others; to the eyes of the others, I'm ethnically ambiguous from the speaking point of view [laughs]. [...] The last time I was in Rio, I went to give a class in a post-graduate course... and this friend of mine, introducing me to my university colleagues, said: 'look, here's that Portuguese friend of mine'. [...] On the other hand, I don't have a single Brazilian friend in Portugal.” 
Food may serve to assess, in a more or less objective manner, the particular way in which each subject manipulates his different belongings. For Márcio, picanha (filet steak) and caipirinha represent his tie to the first bank; they act as symbolic supports anchoring him to the Brazilian culture. They bridge the cultural journey from the first bank.

"I need picanha, for example, but I don't need to go to the restaurant, I buy it. I make caipirinha at home and it's very good, everybody likes my caipirinha, there are people who go to my house just for my caipirinha."

As with gastronomy, football also plays an identity catalyzer. Through membership or connection to a sports club, it is possible to know the weight - even though residual - of various existing belongings.

"When there are games with Brazil against Portugal, I support Brazil [...] I wouldn't like Portugal to lose, but I'd like Brazil to win."

\section{ROWNEY}

\section{The Intercultural Self}

Rowney is a dental surgeon. He has been in Portugal for 20 years. He has a Luso-Brazilian family. His wife is Portuguese, from Porto, and they have two daughters from a first marriage. Although they were born in Portugal, they were not granted Portuguese nationality, due to the legislation in force at that time. Rowney claims he has the right to belong everywhere: the first, the second and all banks. He sees himself as an ongoing project.

"I feel a citizen of the world. I'm not who I was born as, I'm the one who I constructed, I am what I am, today. If I'm going to be alike tomorrow, I don't know, probably not. Probably, tomorrow I'm going to gather together more things, more knowledge, more experiences and, maybe, I'll be different, I'll have other views, I may even become either a fundamentalist or a more opened individual than I am today. I don't see things with this fixation in time. My life experience was essential for this chameleon-like capacity of mine to adapt."

His adherence to the departure culture manifests itself in his affection for the culinary traditions of Brazil and, then again, by his firm refusal of the Portuguese culinary traditions. His primordial identification is also strongly asserted through affection both for the Portela's samba school and for the Brazilian Flamengo football team (an emotional investment that he does not make in any Portuguese club).

"Don't ask me to support any other school than Portela, it isn't worth it, it's the samba school of my heart, which colors are blue and silver. I religiously watch Portela's parade [...] [laughs], it's a bit of a ritual, there is also a ritual when I sit down to watch Flamengo play, it isn't the same thing to sit down and watch Porto or Benfica play. When Flamengo plays, move away from me, because, then, fanaticism almost borders on madness [laughs]. I have my weaknesses, I'm human. Flamengo is what my heart is, what am I going to do? I can't support any other team. When two teams are playing, you choose one to have a leaning towards, but I can't fix on another team, I can't suffer, it's Flamengo."

If football functions as an important anchor to the culture of departure, this ontological dimension, the call to roots, is reinforced by his food preferences, which are unequivocally Brazilian. 
"I haven't adapted easily from the food point of view; by the time I arrived in Portugal, stews, grilled foods were not part of my diet; I continue, today, to feed myself in the Brazilian way. I hate kale, so green soup is out of the question, Portuguese traditional stew is a dish that doesn't suit me at all; however, codfish, made any way, I eat it, I love it. I have a "loathing" for grilled sardines, I take it as a vision of hell, it's a Dante's well painted image, but on the other hand I love grilled snook fish. There's an identifying with the things, not their nationalities. And I can be proud of having taught my wife doing a lot of the food plates she does today, Brazilian and other type of food."

Through his Portuguese family, his daughters and the nation, symbolized by the anthem that he emotionally intones, this Brazilian immigrant claims his Portugality.

"You put bread to bake in the oven, what comes out? Bread or a butterfly? Bread. Therefore, my daughters are Portuguese, they were born here, daughters of Brazilian parents, but they're Portuguese, I've always felt this. The question is to know which focus you're giving to this question. Officially they aren't; technically, maybe also not. Initially, I kept myself completely Brazilian, a tieless immigrant. The equality, rights and responsibilities' statute transforms me into a Brazilian individual enjoying the same rights and responsibilities as a Portuguese citizen; it's as if I were a Portuguese for fun. The Portuguese national anthem makes a big difference, I have a very curious relationship with the Portuguese national anthem because when I arrive in Portugal and see the eloquence, the speed with which the anthem arrives for the Portuguese, I was completely enchanted by that, so I have a very great affection for the anthem. Today, when the anthem is sung at national team games... for example, a few time ago, Portugal was about to start playing, and we began to sing the anthem "Heroes of the sea, noble people ...", and my daughters were staring at me and they asked me if I knew the entire anthem. Of course I know it, how could I live here for 17 years and not know the national anthem... this anthem makes already a big difference to me. "Portugality" is already very costly to me. I'm never going to stop being a Brazilian."

\section{The Metamorphosis}

As we saw in Márcio's case, it is also the view of others that allows us to objectify the brought about transformation and become aware of this identity disjunction.

"I'm not Rowney all the time, many times not as directly, but more by the backdoor. I'm "The Brazilian”, "oh, it's that Brazilian doctor". This gives you a dimension of the importance of each person's behavior as an individual outside his own country; you are your country's representative. I'm not Brazilian, but I can't say that I'm Portuguese neither."

\section{"Immigraland": the Escape through the Third Bank}

With one foot on each bank, where he laid down his roots, Rowney is like an "orchid", travelling through space in search of the third bank, the third place, the place that doesn't exist anywhere else, or which could be every place on Earth.

"Of course I have roots; there is no denying it, but it doesn't mean I can't be fine where I am. The orchid roots are inserted in the tree that supports them, but sometimes they reach the ground; the orchid roots are very long, it's the plant that's small. The impression I have, is that Brazil is too small, 
Portugal is too small. If, for any reason, I had to go to live in Russia, or Bulgaria, I'd go, I don't know if I'd have more or less difficulty, but I wouldn't face it with any apprehension, the fact of going to live in Bulgaria. The emigrant is landless, he has no place in the world, they have to create immediately the "Immigraland" (laughs) because it's a very serious problem, here in Portugal I'm a Brazilian and when I'm in Brazil I'm a Portuguese. "Immigraland" doesn't exist, I don't have a place. Today, when I go to Brazil everybody calls me "the Portuguese guy". There are two cities in the world, I would change Leiria for either of them: Barcelona and Rio de Janeiro, but the latter doesn't exist anymore, it is an extremely violent city, abusively inhuman for my liking. I'm completely mad about Barcelona, captivated, those are the two cities that definitively enchant me from the lifestyle point of view, and this more or less gives you an idea of my way of being, I'm not very into formalities."

\section{NÍVEA}

\section{The Intercultural Self}

Nívea was born in Brazil and has been living in Portugal for 15 years. She gained a degree in Portuguese Literature and worked in various cities in Brazil. She came to Portugal with her husband due to a job offer that he received from a radio station where she had recently started to work. Two years later, her only son was born. Interested in citizenship questions and considering herself a citizen of the world, Nívea requested dual nationality for herself, her husband and her son. Her husband showed some resistance, in contrast to her, who faced the situation as "natural", as she perceived that this act would legitimize the multiple cultural references that she is made of.

“Today I already have Portuguese nationality, i.e. I have dual nationality. After 14 years, I decided to request dual nationality, so my son could benefit all the advantages of being a European citizen. [...] When I said to my husband "I'm going to request Portuguese nationality", he said "Ah, but I don't want to lose my Brazilian one...", and I said "We aren't going to lose our Brazilian nationality; we are going to gain dual nationality!"

She inhabits every cultural world through which she has passed along her social path and consciously lives this metamorphosis.

"I live very well with myself and with others, I'm very happy here, I love it... And I deal well with these differences, which for me are... natural, I don't think about it a lot..."

\section{The Invention of the Third Bank}

Despite all her family living on the first bank, her son, who was born in Portugal, has strengthened this identification with the Portuguese, contributing to a greater integration of the banks inside her.

"All my family is from Brazil, at least as far as I know they all have Brazilian roots. But I say this because my son now changes a lot of things! My son is Portuguese and, as such, ends up having fifty per cent in the blood."

Like Rowney, Nívea recognizes in herself the belonging to the first, the second and all the other banks, considering herself as a project always open to change. 
"I have a great adaptation facility. Even last year we received a proposal to go to Lisbon and my son, the first thing he said was, "Gosh, mum, what about my friends?", and I said "Make new ones... Look at my example, and you are a little over an hour's journey away. Look at my friends, where I left them... nine thousand kilometers away... friends from a whole lifetime, but friends that are real friends don't die, my son! They stay there... When you need them, they are there... and now, today, with the Internet!" So, I always try to pass on this culture to him, that we need to 'always be moving', 'always be renewing', we can't settle..."

The link to the departure culture takes on great significance for them, just as the new Portuguese references that she has been experiencing for several years, translate into a shared attachment between foods, musical and football traditions of both countries.

"I like Portuguese food a lot, it's delicious, and then the codfish... [...] I cook Portuguese and Brazilian food, I love both."

"Music is there, at home, both Brazilian and Portuguese."

"And that way, I win both ways! If Portugal wins, I win, don't I? If Brazil wins I also win, because I have fifty per cent blood in each of my veins, so, I think that in the last World Cup we suffered quite a lot. When Brazil lost, ok, let's support Portugal then. Now, if some day the final were between the two, it's like I said, whichever wins, I'm going to win either way, I'm going to celebrate either way, doubly, first and second place!"

Like Rowney, she has developed strong belongings to either bank of the river, but does not conceive that search as something finished. This reality is objectified by her openness to the world which she wants to hold within her, but never forgetting the bank from which she departed.

"I don't rule out the idea of leaving wherever... [...] If they'd call me, I'd go, straight away! I'd go because I'm thirsty for knowledge. [...] I like learning, I like challenges, I like new cultures... So, if they'd told me that today I should go to the United States, I'd go..."

"So what I'd really like would be to spend January in London, July in Brazil, January in Sweden, July in Brazil... those are my plans!"

\section{ANTÓNIA}

\section{The Bicultural Self}

Antónia has been living in Portugal for 11 years. She came to Portugal to support her oldest daughter who immigrated before and who became pregnant by a Portuguese man, whom she married. She arrived with her husband and two other children, the youngest being only two years old. The departure caused her great suffering, which she still feels today.

"It's... in the head that everything changes, isn't it? Not only daily life... [...] Ah, but we feel different! It's another mentality... [...] And I ask myself: "Is it worth it?” [pause] I don't know... breaking with our family, breaking with our lives and changing everything... I found it very difficult here, only now have I managed..."

She asserts to feel as Brazilian as she was the first day she arrived. 
“No, no girl! I'm one hundred per cent Brazilian! I can't, as much as I try... speak Portuguese, I can't, as much as I try to like living Portuguese daily life... I can't yet, maybe in 10 year's time I'll get there... [laughs]."

"No, no, no... I can't [feel differently], I can't because it's... it's very different, the manner of being Brazilian and the manner of being Portuguese. It hasn't been a happy marriage in that respect."

She affirms the strong sense of belonging to the first bank and tries to recreate it in all contexts, at home and outside, be it in the way of speaking, in the culinary traditions, in the music she listens to, in the religion she practices.

"[...] both in the food, in the way of speaking... and I want to continue being Brazilian! We are Brazilians all the time, 24 hours a day, both outside and at home, there is no reason... The food at home... I only eat Brazilian food, only. And I also brought religious culture, didn't I? Which is Yemaja, it's... that's what we worship. I'm fond to her and there's also a group of Brazilians here who pray with me, we perform the rituals, we follow this faith... I'm a spiritualist, which is something more common in Brazil, isn't it? What else?... Music... I only listen to Brazilian music."

Nevertheless, without admitting it, Antónia already has one foot on the other bank, objectively and subjectively, be it through identification with Portuguese music, with the friendships that she has established or with some social habits that she has acquired.

“That's right... now I'm listening to fado a lot [...] I'm developing other habits, waking up later, but just a few times, because I'm used to getting up early in Brazil... but here the times are different... look, I'm already going to the café too... [laughs] [...] but I think it's... it's good, to go out... because here we don't go out a lot."

"There are still good people here... I have some friends, not many... but I know a lot of people already... good people. [...] We need other people... I like to stay right here, which is where I live, to live with people... and I end up meeting people who come to the office... who ask me to pray..."

\section{Between Banks and Affections}

Her refusal to integrate new cultural references in herself translates into the affirmation that she and her family should maintain an unbreakable link to the first bank. Nevertheless, her youngest son causes her great worry on this question, feeling himself a Portuguese, against her will.

"I think that yes [he has necessarily to maintain his Brazilian identity], because that's what we are, [...] it's our identity! And by the fact that we live in a different place, it doesn't mean we have to be different, does it? Why are we going to change? This fits for everybody [her family], we are Brazilians, but my son... he's having problems because he says that at home he can't speak Portuguese, he can't be Portuguese because we're Brazilian... he arrives at school and he can't be... he isn't considered Portuguese, everyone calls him "Brazilian" and he thinks of himself as a Portuguese, so he has a serious identity problem, very serious!"

Antónia is experiencing today a constant dilemma between the strong sense of the first bank, coupled with the desire to return to her place of origin, and wanting to stay with her youngest son, seen as an "other" in the family, as the Portuguese one, but loved and respected. This internal battle leads Antónia to ambivalence between the desire to change him and accept him as he is. 
"We are all Brazilians... At home, he's the only one like that... It seems that what other people tell him is more important than what we do..."

“There are times when he doesn't really understand very well his position... he calls himself a Portuguese, he thinks of himself as a Portuguese! By the time he discovers, you'll see..."

"Well... he's lived his whole life here, hasn't he? I can get it... but it's in Brazil that he was born, and that's his country... and one day we're going back, and he'll be going too..."

"[...] but my son thinks of himself as Portuguese... he hates my food, he doesn't like Brazilian music and he wants... the other day I told him: "Sing, my son, for mum to hear a little of the national anthem", and he replied: "...To the arms, to the arms", and I said: "that isn't your national anthem, my son, I'm sorry! That one's from here, ours is a different one!", and he said "Oh, I don't like it". And another day, a customer was here and said "Oh, I'm going to Brazil, I'm going to visit...", and he said "Be careful, be careful: there, in Brazil it's so dangerous, you're going to catch a stray bullet"... I said: "Don't you talk like that about your country, my son!" No... he hates everything that comes from Brazil..."

Conversely, her grandson, born in Portugal, son of her oldest daughter with a Portuguese man, represents a strong link to the second bank, which cannot be denied by Antónia.

"But this grandson of mine makes us forget so many things... and, on the other hand, makes us fight more for our rights here! [...] It's true, he is a blessed boy! It's a delight watching him... he gives us so much happiness."

\section{Conclusions}

Contrary to what is normally assumed in cultural studies about immigrants, which tend to explain social and mental pathologies as a result of emigration, especially amongst children of immigrants, allegedly tormented because of living divided between different cultures, we believe that these individuals have the capacity to live comfortably in different worlds without any type of pathology.

We're in front of different ways of managing identifications in a heterogeneous life trajectory analyzed here, which we simply denominated between the first and the second cultural bank. There are similarities between the four voices, but it's more from the differences that we wish to take some conclusive readings.

Focusing ourselves on each subject's particularities and singularities, we have tried to understand the way in which each one manages their subjectivities within a different reality from the one they've left. They inhabit a different reality today, although some identify themselves with one of the banks, while others welcome internally the multiple experiences found between the banks.

It is possible, in these four cases having Brazil as a first bank and Portugal as the second, to perceive those who admit themselves as citizens of the world, who don't see the second bank as the culture of arrival, but rather as a living gerund, following their paths which always take them to other ongoing projects, as in the explicit case of Nívea and Rowney; there are others that use the second bank as a passport to return to the first with some dreams fulfilled, believing that on returning they will still be the same, that they return to the same reality they left, when neither one nor the other ends up happening, as is Antónia's case. There are also others, who sometimes seem to be like Márcio, who accept being the stereotype of accepting to be between the two forms of being, designating themselves 
as "ethnically ambiguous", by the perceived classification through others' conceptions of those who live between banks.

The identity process is a path of constant acknowledgements based on the reflexivity and agency of each subject, in a game between the possible and the desirable, which seeks balance between the self and the other, to attribute meaning and continuity to the self. Each subject includes, thus, in a syncretic manner, the plurality of references available, possessing, as told by Cuche [8], "an identity of variable geometry".

The analysis of these four Brazilian immigrants shows us that the immigrated is seen as a stereotyped category, without personal identity. This classification does not correspond to the real life immigrant, as he manages the different belongings to be himself.

As the voices tell us, each immigrant is the result of a construction process, joining both the personal identity and the different contexts through which they have passed. Finally, each immigrant is a multicultural self, living between each cultural departure and each cultural arrival, searching for and constructing his own synthesis from all this diversity in himself. This means that cultures travel in the self, more than people traveling through immigrating cultures.

\section{References}

1. Lages, M.; Policarpo, V.; Marques, J.; Matos, P.; António, J. Os imigrantes e a população portuguesa-imagens recíprocas; ACIME: Lisboa, Portugal, 2006; p. 33.

2. Cruz, M.B. Sessão de Abertura do I Congresso de Imigração em Portugal. In Actas do I Congresso de Imigração em Portugal: Diversidade-Cidadania-Integração, Lisboa, Portugal, Dezembro 2003; ACIME, Ed.; ACIME_Alto Comissariado para a Imigração e Minorias Étnicas: Lisboa, Portugal, 2004; pp. 12-14.

3. SEF Imigração, Fronteiras e Asilo. Relatório de Actividades 2006; Departamento de Planeamento e Formação do Serviço de Estrangeiros e Fronteiras: Lisboa, Portugal, 2006.

4. Souta, L. Multiculturalidade e Educação; Profedições: Porto, Portugal, 1997; p. 36.

5. Vieira, R. Identidades Pessoais: interacções, campos de possibilidades e metamorfoses culturais; Colibri: Lisboa, Portugal, 2009.

6. Vieira, R.; Trindade, J. Migration, Culture and Identity in Portugal. Lang. Intercult. Commun. 2008, 8, 36-49.

7. Mendes, M. Mulheres em Diáspora-Narrativas Identitárias de Mulheres Imigrantes em Portugal, Master Thesis; FPCE_-Universidade do Porto: Porto, Portugal, 2008.

8. Cuche, D. A Noção de Cultura nas Ciências Sociais; Fim de Século: Lisboa, Portugal, 1999; pp. 60, 149-165.

9. Camilleri, C. La culture et identité culturelle: champ notionnel et devenir. In Chocs de cultures: concepts et enjeux pratiques de l'interculturel; Camilleri, C., Cohen-Emerique, M., Eds.; L'Harmattan: Paris, France, 1989; pp. 21-73.

10. Vieira, R. Ser Igual, Ser Diferente: Encruzilhadas da Identidade; Profedições: Porto, Portugal, 1999.

11. Burgess, R. Métodos de pesquisa de terreno II - As entrevistas como conversas. In A Pesquisa de Terreno, Uma Introdução; Burgess, R., Ed.; Celta Editora: Oeiras, Portugal, 1997; pp. 111-133. 
12. Spradley, J. The Ethnographic Interview; Prentice Hall: Upper Saddle River, NJ, USA, 1979.

13. Geertz, C. A Interpretação das Culturas; Livros Técnicos e Científicos (LTC) SA: Rio de Janeiro, Brasil, 1989.

14. Bourdieu, P. La misère du monde; Seuil: Paris, France, 1993; pp. 903-914.

15. Rodrigues, J.C. Antropologia e Comunicação: Princípios Radicais; Edições Loyola: São Paulo, Brasil, 2003; pp. 169-170.

16. Hall, S. A Identidade Cultural na Pós-Modernidade; DP\&A Editora: Rio de Janeiro, Brasil, 1997; p. 91.

17. Vieira, R. Histórias de Vida e Identidades-Professores e Interculturalidade; Edições Afrontamento: Porto, Portugal, 1999; p. 58.

18. Hall, S. Da Diáspora-Identidade e Mediações Culturais; UFMG: Belo Horizonte, Brasil, 2003; p. 27.

19. Sarup, M. Identidade, Cultura e o Mundo Pós-moderno; Edinburgh University Press: Edinburgh, UK, 1996; p. 7.

20. Stoer, S.R.; Magalhães, A. A Diferença Somos Nós-A gestão da mudança social e as politicas educativas e sociais; Edições Afrontamento: Porto, Portugal, 2005; p. 106.

21. Wieviorka, M. A Diferença; Fenda: Lisboa, Portugal, 2002; pp. 92-93.

22. Giddens, A. As consequências da modernidade; Celta Editora: Oeiras, Portugal, 1992; p. 64.

(C) 2010 by the authors; licensee MDPI, Basel, Switzerland. This article is an Open Access article distributed under the terms and conditions of the Creative Commons Attribution license (http://creativecommons.org/licenses/by/3.0/). 